\title{
AN INTEGRATIVE MODEL OF COGNITIVE IMAGE AND CITY BRAND EQUITY
}

\author{
Arianis CHAN* \\ Universitas Padjadjaran, Business Administration Faculty of Social and Political Science, \\ Jatinangor, Sumedang, West Java, 45363, Indonesia, e-mail: arianis.chan@unpad.ac.id

\section{Dadan SURYADIPURA} \\ Universitas Padjadjaran, International Relations Faculty of Social and Political Science, \\ Jatinangor, Sumedang, West Java, 45363, Indonesia, e-mail: suryadipura@unpad.ac.id

\section{Nenden KOSTINI} \\ Universitas Padjadjaran, Business Administration Faculty of Social and Political Science, \\ Jatinangor, Sumedang, West Java, 45363, Indonesia, e-mail: nenden.kostini@unpad.ac.id
}

\section{Asep MIFTAHUDDIN}

Universitas Padjadjaran, Business Administration Faculty of Social and Political Science, Jatinangor, Sumedang, West Java, 45363, Indonesia, e-mail: asep17012@mail.unpad.ac.id

\author{
Citation: Chan, A., Suryadipura, D., Kostini, N., \& Miftahuddin, A. (2021). AN INTEGRATIVE MODEL OF COGNITIVE IMAGE \\ AND CITY BRAND EQUITY. GeoJournal of Tourism and Geosites, 35(2), 364-371. https://doi.org/10.30892/gtg.35214-660
}

\begin{abstract}
This study aims to assess the effect of cognitive image and city brand equity on total city branding, evaluation of word-ofmouth (WOM), brand commitment and intention to revisit. The conceptual model used in the impact study of the impact of tangible and intangible elements related to city branding. Involving 423 tourists visiting four cities in West Java, Indonesia as an assessment of the variables studied. The results showed that the conclusions on cognitive image, city brand equity and brand commitment were low. While the other categories are classified as good. These findings also reveal the analysis of the relationship between variables, including cognitive image variables that have a significant effect on city brand equity. Cognitive image is explained through the dimensions of quality experience, tourist attraction, infrastructure environment, and outdoor activities. Meanwhile, city brand equity is measured by brand awareness, brand loyalty, and brand value. Furthermore, the results also show that the variable city brand equity has a significant effect on the variable word-of-mouth (WOM), brand commitment, and the intention to revisit. The most significant influence exerted on brand commitment. These results indicate that the condition of city brand equity affects how wordof-mouth, brand commitment, intention to revisit. This study only discusses part of the tourism activities carried out in these four destinations, so to confirm these findings it is necessary to carry out further research on various destinations and events.
\end{abstract}

Key words: city branding, cognitive image, word-of-mouth, brand commitment, city brand equity

\section{INTRODUCTION}

A city has an identity inherent in itself, such as heritage, economy, socio-culture, technology and icons that are reconstructed into such a product or brand from a marketing standpoint. Understanding and appreciating this identification and fostering interaction with stakeholder groups and separating cities from growing global competition are challenges for related stakeholders (Bartis and Madlwabinga, 2020; Mohd Shariff and Zainol Abidin, 2020; Utomo et al., 2020). However, even though the city has implemented a marketing approach to achieve its organizational strategies and goals, this transposition raises strategic difficulties, primarily due to the distinctive existence of the locations in some cities (Kavaratzis and Kalandides, 2015). Transposition could be undertaken to analyze cities as brands using traditional typologies in brand analysis, thereby giving much weight to urban management stakeholders (Ilieş and Ilieş, 2015). In reality, a place might be a brand such as Bali (Indonesia) and KwaZulu-Natal (South Africa) (Mastika, 2020; Mlambo and Ezeuduji, 2020) and a brand name was its title a destination that strategy is to make the people recognize the brand and build connections that visitors want and enjoy. Besides, there could be fewer than one brand in a city (Kavaratzis, 2020). Brand equity is described by Zenker and Braun (2017) in which a place throughout the framework of global marketing is a crucial element and promotes economic growth (Bernhard and Olsson, 2020; Jászberényi and Miskolczi, 2020), helps to recruit and to hold citizens and companies. Therefore, it adds importance and serves as a providing mechanical for regional attractiveness and profitability.

Increasing the brand value of a city requires understanding and engaging actively with local stakeholders as they can collectively plan a specific storyline that improves the reputation of the venue and strengthens the place brand (Cleave and Arku, 2020; Eugenio-Vela et al., 2020). There are two very significant categories in the stakeholder community to test city brands: residents and visitors. Meanwhile, the value of tourism to the city's grand plan is that citizens not only are they customers, they are part of the setting, but they also get the power to say the city to future tourists, investors or even

\footnotetext{
* Corresponding author
} 
prospective new residents (Gómez et al., 2018). In this way, people have various positions in creating the city's brand and are part of the landmark and are thus considered representatives or founders of the city. Much of the city brand equity analysis focuses on the study of brands or areas of business brand equity (Kladou et al., 2017) founded on Aaker proposal (Aaker, 1996) that this condition is justified on two grounds that arise from one another and. Each place's marketing is inspired by traditional marketing strategies, provided that marketing strategies and concepts refer not only to products and services but also to areas, countries and towns. As a result, city brand value has a similar basis to brand value, in general, it has been recognized as a key component tool for competitive advantage, plays a primary role in all local businesses and is important for stakeholders to consider when designing a tourist destination (Ashton and Ashton, 2015; Kankhuni, 2020) Another important point is that of all the conceptual models of brand value, the paradigm of Aaker (1996) stands out for its profound influence on the subject in the research.Place brand equity research is primarily relevant for tourism brand equities, with an emphasis on destination brands and brand culture. This research focuses on the dimensions of travel, heritage and tradition centred on Anholt's hexagon brand model (Anholt, 2006). However, some studies have taken into account the views of tourists regarding different cultural assets or compared the tourist viewpoint with the perceptions of various stakeholders such cultural and regional backgrounds, while others vary from other cultural and regional backgrounds depending on the particular stakeholder community (Acuti et al., 2019; Toros and Gazibey, 2018). In order to fill this gap, the aim of this research is to evaluate city brand equity in West Java using a model centred on tourism perceptions, to analyze the key drivers of cognitive image and its effect on brand commitment, intent to revisit and word-of-mouth (WOM).

This study also helps to minimize the scarcity of models and city brand sizes and compares the findings of four different regions, such as the Tsaur (2017) research, which shows that from the point of view of the effects of tourism, several studies have examined the construction of the visitor population conflict in several regions and a strategic region that promotes many economic activities, including tourism, fisheries, power plants, agriculture, markets and social factors such as coastal villages, schools and other public facilities (Munawir, 2019; Windupranata et al., 2020).

Sukabumi, Garut, Pangandaran, Bandung are cities in West Java, Indonesia is the main city in West Java and is a destination for natural, historical and cultural tourism, which was considered to be the best city brand in West Java (Sukmayana and Mukti, 2017; Venus et al., 2019; Windupranata et al., 2020). This research examines cognitive image aspects that have an effect on city brand equity in Indonesia through a quantitative method analysis approach. The structural analysis describes how cognitive image decreases city brand equity, word-of-mouth (WOM), brand commitment and intention to revisit. This research will yield constructive results for the tourism sector by providing proof of key behavioural characteristics.

\section{MATERIALS AND METHODS}

\section{City Brand Equity}

At this current phenomenon, brand equity is no longer just talking about products/services within the company. There are various forms currently in branding, ranging from advertising to the long-term development plan, sticks to the economic structure, physical appearance and identity of a city (Joo and Seo, 2018). Place or city is also another attribute in brand equity (Górska-Warsewicz, 2020). Brand equity can be explained as the continuous accumulation of loyalty, awareness and financial value for a brand (Clarke and Kredens, 2018). Several previous studies state that a city brand's main characteristics are an academic concept (Zenker et al., 2017). Local stakeholders' position is still unclear in branding practices in cities and other places (Lindstedt, 2015). This is a concern for some researchers and encourages them to consider the local concerns in it (Zenker et al., 2017). This eventually led some researchers to develop ideas for brand co-creation in the context of a place (Martin and Capelli, 2018). In branding in an area, many governments, consultants and researchers interpret product standards, public relations and identities where the product is a country, or a city or a region (Kavoura and Bitsani, 2014).

Through this, it will have an impact on local government (provinces, towns and counties) a certain amount of control in debt agreements, budget management and budget execution to give confidence in being responsible for designing and implementing strategies with stakeholders and of course also contributing support (Lindstedt, 2015; Zeng et al., 2020) However, in thinking about branding for a city or place, there needs to be a form for overall planning and management to form a more strategic development and gather political aspirations from local government (Cassinger and Eksell, 2017).

There is a practical execution of city branding which consists of three methods, namely promotional campaigns, forming a distinctive building as a bulge for the city or finding other ways to integrate structures that become protrusions into promotional activities and provide various activities in the city (Makarov and Illarionov, 2020). For some other academics, it is stated that branding is a planning process that aims to form the identity of the brand itself and that the emphasis on literature is often the content of branding planning (Mariutti and de Moura Engracia Giraldi, 2019). City branding itself was first put forward by Braun et al., (2018) who gave the fact that city branding is implemented in government in an urban context. Also, city branding is seen as the subject of political decision-making, making it inseparable from politics or administrative procedures, so that city branding becomes part of the political process (Aziz et al., 2015).

\section{Cognitive Image}

Image is one part of a brand that receives the most attention in academic literacy (Iordanova, 2015). For a long time, the image has been described as one of the dimensions of a brand, but this view has changed where the image formation is no longer a brand, building an image is the closest step in branding, but there is one other aspect that is still missing, namely the identity of the brand itself (Salim et al., 2015). The picture in a location is a construct that refers to the accepted characteristics and depends on the meaning of a photograph that may alter or evolve, the effect is not only on an attitude but also on individual behaviour. The image, in this case, is also related to describing the expectations of a destination. 
Currently, the image has been formed at different levels (Mason and Moretti, 2015).

The image today does not always discuss products or services developed by the company. Other aspects such as culture, tourism, technology, education, data, people, politics, places or cities are also included (Acharya and Rahman, 2016). Nowadays, it is inevitable that all destinations or places in the world aim to enhance their international reputation. An image built in a place or city will significantly influence government policy and benefit foreign businesses who are considering injecting capital investments into a country (Hsieh et al., 2017; Lee and Lee, 2019). The cognitive image will be influenced by national, political and economic identities different from branding as understood by the commercial sector. Images themselves will build awareness and reduce the risk of associating consumers when visiting a place with little information they know (Petrevska and Cingoski, 2017). In this case, belief and knowledge of an object and affective image are related to a sense of an object (Martens and Reiser, 2019). Besides, there has been researching which states that cognitive image has a relationship with brands. Similarly, Gartner (2014) found that image is an important central feature for brand equity in destinations. In the city brand equity will increase if there is a positive reputation from the image in the city.

\section{Word-of-mouth}

Word-of-mouth (WOM) or can be said to be an exchange of opinions regarding products and services offered by the market (Grohs et al., 2020). Word-of-mouth can be one of the most effective advertising tools in changing consumer attitudes. WOM can be seen from various studies that have demonstrated that word-of-mouth effectively influences consumer behaviour (Chin et al., 2018). The definition of word-of-mouth has been described by several experts and is entirely inspired by Chen et al. (2018). They focused on the informal aspects of word-of-mouth communication, the independence of communicators from commercial sources, and the phenomenon of information dissemination. Word-of-mouth communication itself can occur through face-to-face, telephone, email, mailing lists, and other communication tools (Reijonen et al., 2017). Word-of-mouth can be affected by marketing efforts such as advertising, media relations, public relations, and spontaneous conversations between two individuals and by satisfying or unsatisfactory purchasing experiences (Thi et al., 2016). In the current phenomenon, the practice of word-of-mouth can often be seen when someone is looking for a review or opinion on a product (Papadimitriou et al., 2018). Based on the findings of research by Sumartias and Nuraryo (2017) who see that through word-of-mouth, when there is a negative opinion, information is spread among customers, it will affect brand equity. Word-of-mouth is seen as having a positive or negative influence on customer perceptions of the brand. Besides, other research states that the impact of consumer perceptions on brand equity will weaken if consumers are very attached to word-of-mouth (Papadimitriou et al., 2018).

\section{Brand Commitment}

Customer commitment has become a common topic in marketing. Commitment occurs when individuals begin to have a psychological attachment and develop more and more to an object (Ahn et al., 2016). The concept of commitment comes from social psychology (Sannassee and Seetanah, 2015). Besides, this commitment is also one of the images associated with place attitudes (Coffin, 2019). Brand commitment is a psychological or emotional connection between consumers and brands or organizations (Fullerton and Kendrick, 2017). Besides, brand commitment consists of calculative dedication (rational, economic calculation) and affective commitment (emotional and social sentiment). Brand commitment can also increase brand image because committed individuals are motivated to continue to support the brand and have a positive relationship with brand associations (Kladou et al., 2017). In the context of destinations, commitment to brands is a psychological connection with city brands.

\section{Intention to Revisit}

A person's experience with what they have experienced can be considered the most significant influence in choosing to return to that destination (Booyens and Rogerson, 2015). In other studies, it is stated that when someone has experienced a memorable experience, then involving the components of hedonism and local culture, and there is a positive impact on the intention to revisit to the destination ( $\mathrm{Li}$ et al., 2017). Aspects on the willingness to return to visit, a tourist, will relate to cognitive components, such as quality, value, and image and they can also be related to affective details such as satisfaction and pleasure. The destination image is a critical component that will be the primary consideration for people to choose and the willingness to return. Tourists with a good picture of the location would have a better attitude towards their experience. In financial and non-terms, the perceived costs may affect the consequent plan to purchase, purchase and return tourist goods to the same destination. The right destination image will positively impact where tourists will have the desire to return to that destination (Reitsamer and Brunner-Sperdin, 2015).

\section{Method}

This research is a quantitative descriptive study by looking at the field's facts (Al-ansi et al., 2020). The variables used in this study consist of the independent variable cognitive image, the intervening variable brand equity and the dependent variable word-of-mouth (WOM), brand commitment, and intention to visit. Data were collected through online surveys. The research location is in Jawa Barat, Indonesia. This research population is tourists visiting Jawa Barat with a total sample of 423 people, illustrated in Table 1. Researchers use a systematic and sophisticated theoretical approach. Method to resolve the objectives of the report. This is made up of eight, as reported in Figure 1. Stage 1 specifies the domain and structures relevant to the encounter. Tourist inconvenience by evaluating previous literature and secondary data (i.e., newspapers and government reports). Stage 2 produces two focus group discussions with business, academics and experts, accompanied by semi-structured interviews with visitors. Stage 3 includes the administration of the first survey questionnaire. Finally, stage 4 consists of 
refining and purifying the produced items by conducting an exploratory factor analysis (EFA) and then removing unloaded or insufficient items according to the standard criteria. A second survey questionnaire, including additional structural designs, was administered at stage 5. Stage 6 carried out a solid evaluation of the products to verify their reliability and validity, including the EFA, confirmatory factor analysis (CFA), Model fit indices, convergent validity and discriminatory validity. Stage 7 measures the proposed structural model predictions and path coefficients using structural equation modeling (SEM) and partial minimum squares (PLS). Finally, the effects of the structural model were established in stage 8.

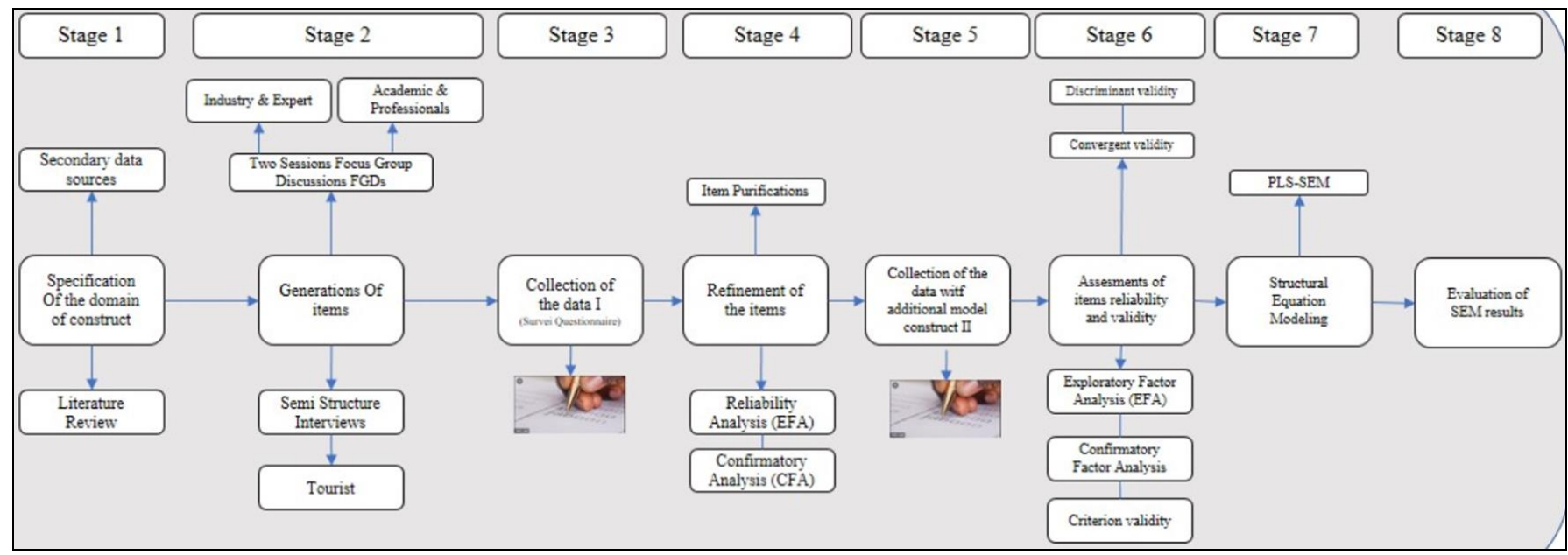

Figure 1. Research design and process

\section{RESULTS DISCUSSIONS}

To achieve the objectives, we choose the study. It is possible to use a sampling unit, namely tourists visiting the tourist destinations of Jawa Barat, Indonesia to be evaluated, with criteria and scales that have been prepared in advance. Concerning periods, to obtain greater homogeneity in answers and suitability for questions that refer to specific moments, fieldwork was adjusted for a limited time frame, focusing on the December 2019 holiday season. After a comprehensive analysis of the scales and constructs defined, cognitive Image toward city brand equity was considered unidimensional constructs reflectively linked to their indicators. City brand equity was described as a multidimensional construct with dimensions related reflectively to their indicators and formatively to the construct. This study conceptualizes brand equity as a second-order structure with three first-order dimensions as formative indicators and the influence of cognitive image toward city brand equity, city brand equity toward word-of-mouth, brand commitment, and intention to revisit as contributors to the construction of city brand equity. Studies have included second-order models to measure city brand equity (Li et al., 2017).

Table 1. Visitor profiles

\begin{tabular}{|l|c|c|}
\hline Variable & Frequency & Per cent \\
\hline Gender & & \\
\hline Male & 180 & 42.55 \\
\hline Female & 243 & 57.45 \\
\hline Age & & \\
\hline $17-25$ & 220 & 52.01 \\
\hline $26-45$ & 129 & 30.50 \\
\hline 46.65 & 74 & 17.49 \\
\hline Education & & \\
\hline High school & 90 & 21.28 \\
\hline Diploma & 16 & 3.78 \\
\hline Undergraduate & 244 & 57.68 \\
\hline Graduate & 73 & 17.26 \\
\hline Household income per month & & \\
\hline <Rp. 3.600.000 & 232 & 54.85 \\
\hline Rp.3.700.00- Rp.5.000.000 & 19 & 10,5 \\
\hline Rp.5.000.000- Rp.10.000.000 & 48 & 26,5 \\
\hline$>$ Rp. 10.000.000 & 84 & 46,4 \\
\hline
\end{tabular}

Table 2. Statistics descriptive

\begin{tabular}{|l|c|c|c|c|}
\hline \multicolumn{1}{|c|}{ Variable/Dimensions } & $\begin{array}{c}\text { Number } \\
\text { of items }\end{array}$ & $\begin{array}{c}\text { Minimum } \\
\text { score }\end{array}$ & $\begin{array}{c}\text { Maximum } \\
\text { Score }\end{array}$ & Mean \\
\hline Cognitive Image & & & & \\
\hline Quality Experience & 6 & 1 & 5 & 4.05 \\
\hline Tourist Attraction & 5 & 1 & 5 & 3.84 \\
\hline Infrastructure Environment & 5 & 1 & 5 & 3.72 \\
\hline Outdoor Activities & 2 & 1 & 5 & 3.93 \\
\hline City Brand Equity & & 1 & 5 & \\
\hline Brand Awarness & 4 & 1 & 5 & 4.03 \\
\hline Brand Loyalty & 3 & 1 & 5 & 3.81 \\
\hline Brand Value & 4 & 1 & 5 & 3.75 \\
\hline WOM & 3 & 1 & 5 & 4.11 \\
\hline Brand Commitment & 2 & 1 & 5 & 3.83 \\
\hline Intention to revisit & 1 & 2 & 5 & 4.17 \\
\hline
\end{tabular}

Table 3. The goodness of fit model

\begin{tabular}{|l|c|c|}
\hline Indicators & Criteria & Score \\
\hline Root Mean Squared Error (RMSEA) & $<0.08$ & 0.056 \\
\hline Comparative Fit Index (CFI) & $>0.800$ & 0.885 \\
\hline Tucker-Lewis Index (TLI) & $>0.800$ & 0.860 \\
\hline Standardized Root Means Residual (SRMR) & $<0.100$ & 0.061 \\
\hline
\end{tabular}

Based on the results of data processing, it was found that the community's assessment of cognitive image, city brand equity and also brand commitment was still relatively low as indicated by the average score which was generally less than 4 . For WOM and Intention to Revisit were good with an average score of more than 4 can be seen in Table 2 . WOM is also likely to affect travelers' destination choices significantly (e.g., Papadimitriou et al., 2018; Fernandes and Fernandes, 2018). In tourism, repeat visits have also been accepted as an essential phenomenon at the economy level as a whole and for individual attraction. Indeed, many travel destinations rely heavily on repeat visitors (Li et al., 2020; Rodrigues et al., 
2019). This study aimed to determine the effect of cognitive image on brand equity and its impact on word-of-mouth, brand commitment, and Intention to revisit. The analysis technique used is structural equation modelling (SEM). There are two models in SEM, namely the measurement model and the structural model. However, before discussing the measurement model and structural model, the research model must meet the model fit criteria such as the Root Mean Squared Error (RMSEA), the Comparative Fit Index (CFI), the Tucker-Lewis Index (TLI), and the Standardized Root Means Residual (SRMR). The analysis results found that all the criteria for the fit of the model were appropriately met, so it can be concluded that the model has a high level of compatibility with the data can be seen in Table 3 .

Table 4. Measurement model

\begin{tabular}{|l|c|c|c|}
\hline \multicolumn{1}{|c|}{ Variable/Dimensions } & $\begin{array}{c}\text { Number of } \\
\text { dimension/Item }\end{array}$ & Loading* & $\begin{array}{c}\text { Composite } \\
\text { Reliability }\end{array}$ \\
\hline Cognitive Image & $3^{+}$ & $0.667-0.890$ & 0.877 \\
\hline Quality Experience & 6 & $0.444-0.688$ & 0.760 \\
\hline Tourist Attraction & 5 & $0.543-0.736$ & 0.792 \\
\hline Infrastructure Environment & 5 & $0.586-0.796$ & 0.824 \\
\hline Outdoor Activities & 2 & $0.847-0.881$ & 0.855 \\
\hline City Brand Equity & $3^{+}$ & $0.884-0.952$ & 0.894 \\
\hline Brand Awareness & 4 & $0.626-0.775$ & 0.781 \\
\hline Brand Loyalty & 3 & $0.814-0.863$ & 0.869 \\
\hline Brand Value & 4 & $0.664-0.794$ & 0.777 \\
\hline WOM & 3 & $0.748-0.912$ & 0.894 \\
\hline Brand Commitment & 2 & $0.336-1.000$ & 0.876 \\
\hline Intention to revisit & 1 & 1.000 & 1.000 \\
\hline
\end{tabular}

*) p-value $<0.05 ;+$ ) dimension
Table 5. Result of Hypotheses Testing

\begin{tabular}{|c|c|c|c|c|}
\hline & Std.all & Std.Err & z-value & $\mathrm{P}(>|\mathrm{z}|)$ \\
\hline $\begin{array}{c}\text { Cognitive Image } \\
\rightarrow \text { City Brand Equity }\end{array}$ & 0.815 & 0.137 & 7.289 & 0.000 \\
\hline $\begin{array}{c}\text { City Brand Equity } \\
\rightarrow \text { WOM }\end{array}$ & 0.855 & 0.102 & 13.597 & 0.000 \\
\hline $\begin{array}{c}\text { City Brand Equity } \rightarrow \\
\text { Brand Commitment }\end{array}$ & 0.989 & 0.093 & 14.735 & 0.000 \\
\hline $\begin{array}{c}\text { City Brand Equity } \rightarrow \\
\text { Intention to revisit }\end{array}$ & 0.774 & 0.117 & 12.526 & 0.000 \\
\hline
\end{tabular}

The validity analysis results refer to the loading factor value greater than 0.500 or the p.value less than 0.05 , while the reliability refers to the composite reliability value greater than 0.600 . The analysis results found valid and reliable

items with a loading factor value of more than 0.500 , except for brand commitment items; one thing was found with a value of less than 0.500. However, this item had a p-value $<0.05$, which stated that this item was significantly able to measure brand commitment variable can be seen in Table 4 and Table 5. In general, the loading factor value for the second-order can be seen in Figure 2. The influence analysis explains the effect of cognitive image on city brand equity and its impact on word-of-mouth (WOM), brand commitment and intention to revisit.

\section{Cognitive Image > City Brand Equity \\ The cognitive image} component is one that is used in forming city brand equity in a place, in addition to the affective and conative components (HernándezMogollón et al., 2018). Several studies have shown that the mental image is related to the destination brand and city brand. Cognitive image will also increase brand equity (Han et al., 2018; Leković et al., 2020).
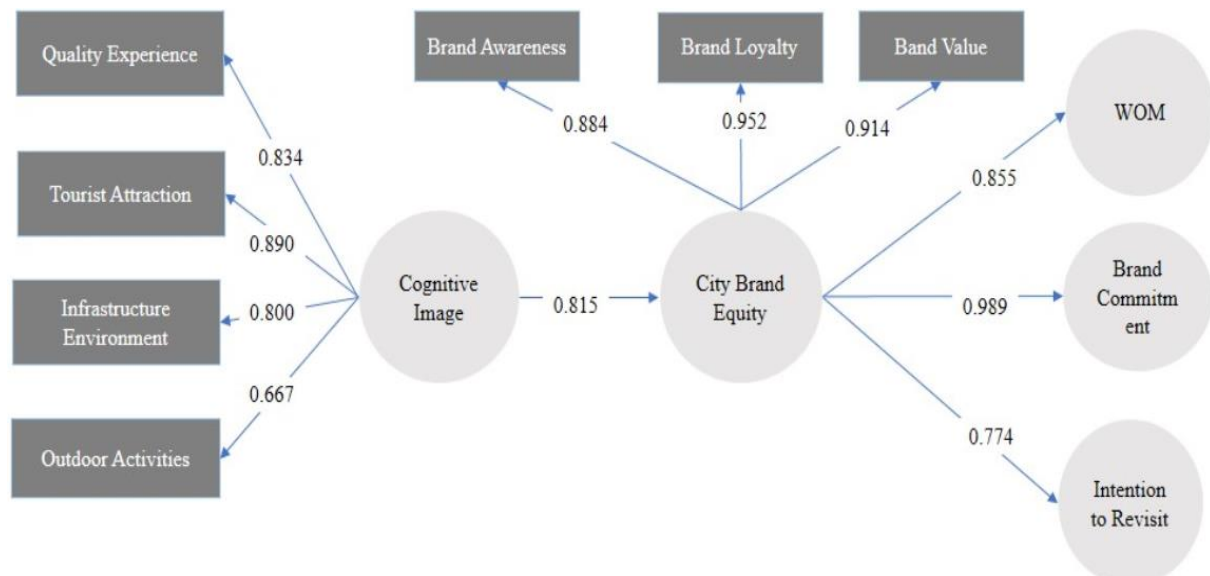

Figure 2. Research

\section{City Brand Equity $>$ WOM}

WOM is an opinion of the nature of service, product or reliability, which passes from one person to another (Jabreel et al., 2018; Park et al., 2019) It should be noted that WOM communications can be either positive or negative, all of which are the product of customer experience. In the future, destinations such as goods and brands, could be recommended to other visitors, such as relatives, friends and acquaintances. Besides, in a variety of tests, WOM has actions with significant implications in destination image testing. Melewar and Skinner (2020) demonstrate how brand equity affects customer response, namely loyalty and WOM. Brand loyalty and perceived value have also been investigated and evaluated as a word-of-mouth antecedent dimension.

\section{City Brand Equity > Brand Commitment}

A brand's dedication is a psychological connection to a city brand in the sense of a destination. The experience of tourists in a destination encourages them to view the brand, which results in greater loyalty, as a desire to revisit or buy (Mangano and Ugolini, 2020; Sánchez-Rivero et al., 2020). People are one of the most significant internal stakeholders in the region, and those with a more robust understanding of the importance of the city brand, a higher degree of engagement, and a more significant effort to do so (Ahn et al., 2016). Commitment, as an emotion, is also a key element in creating brand equity, since it reflects the desire of people to engage in the improvement of their city's brands (Ahn et al., 2016).

City Brand Equity > Intention to Revisit

According to Tosun et al. (2015), a tourist with a good picture of a destination often has a positive attitude about the 
encounters he had in that place. Stylos and Bellou (2019) conclude that tourists' intention to revisit a destination is directly affected by their connection to the spot through emotional relations between tourists and the goal. One might also assume that a tourist who visited the city is more likely to revisit it than a tourist who comes to the city for the first time.

Ching-Cheng and Der-Jen (2015) argue that brand equity is precious and is a crucial concept in the competitiveness of the tourism industry, in line with their plan to revisit it. Tourist loyalty and high brand value, according to Thi et al. (2016) are directly linked to the desire to revisit the site (Koodsela et al., 2019; Wassler et al., 2018).

The calculation results found that the variable cognitive image had a significant effect on city brand equity as indicated by the p-value $<0.05$ and with the magnitude of the influence of 0.815 standard deviations. Furthermore, the variable city brand equity significantly influences word-of-mouth (WOM) variable, brand commitment, and intention to revisit. The most significant impact was given to the brand quality with a magnitude of 0.989 .

\section{CONCLUSION}

Because this study's scope is new to the literature, it is necessary to precisely identify the elements of the cognitive image that form city brand equity in the area of city branding. To achieve this, the researcher conducted a literature review and a qualitative study to determine the factors identified by tourists that form a cognitive image. The results show five dimensions: the first dimension refers to a cognitive image, the second dimension relates to city brand equity and three other dimensions, namely word-of-mouth (WOM), brand commitment, and intention to revisit.

This dimension was then validated using factorial analysis confirmation. Acceptable values were found for the overall fit of each measurement and correlation's model, validity, and reliability. Therefore, the analysis results found that the variable cognitive image has a positive and significant effect on city brand equity, and city brand equity has a positive and significant contribution in building word-of-mouth (WOM) and brand commitment.

\section{Acknowledgements}

The authors wish to thank Universitas Padjadjaran, which funded the study through internal research grant year 2020 budget based on contract number: 1827/UN6.3.1/LT/2020

\section{REFERENCES}

Aaker, D.A. (1996). Measuring Brand Equity Across Products and Markets. California Management Review, 38(3), 102-120. https://doi.org/10.2307/41165845

Acharya, A., \& Rahman, Z. (2016). Place branding research: a thematic review and future research agenda. International Review on Public and Nonprofit Marketing, 13(3), 289-317. https://doi.org/10.1007/s12208-015-0150-7

Acuti, D., Grazzini, L., Mazzoli, V., \& Aiello, G. (2019). Stakeholder engagement in green place branding: A focus on user-generated content. Corporate Social Responsibility and Environmental Management, 26(2), 492-501. https://doi.org/10.1002/csr.1703

Ahn, Y.J., Hyun, S.S., \& Kim, I. (2016). City Residents' Perception of MICE City Brand Orientation and Their Brand Citizenship Behavior: A Case Study of Busan, South Korea. Asia Pacific Journal of Tourism Research, 21(3), 328-353. https://doi.org/10.1080/10941665.2015.1050422

Al-ansi, A., Han, H., Kim, S.S., \& King, B. (2020). Inconvenient Experiences among Muslim Travelers: An Analysis of the Multiple Causes. https://doi.org/10.1177/0047287520934870

Anholt, S. (2006). Competitive identity: The new brand management for nations, cities and regions. Competitive Identity: The New Brand Management for Nations, Cities and Regions. https://doi.org/10.1057/9780230627727

Ashton, A.S., \& Ashton, A.N.N.S. (2015). Developing a Tourist Destination Brand Value: The Stakeholders 'Perspective. Tourism Planning \& Development, 12(4), 398-411, http://dx.doi.org/10.1080/21568316.2015.1013565

Aziz, N., Friedman, B.A., \& Ilhan, H. (2015). The impact of nonprofit organizations on the intent to visit Turkey: An empirical test using the theory of planned behavior. Place Branding and Public Diplomacy, 11(3), 175-189. https://doi.org/10.1057/pb.2015.2

Bartis, H., \& Madlwabinga, Z. (2020). Residents' perceptions of the socio-cultural impacts of tourism: A case study of the Tokyo sexwale community in Jeffrey's Bay, South Africa. African Journal of Hospitality, Tourism and Leisure, 9(3), $232-245$. https://doi.org/10.46222/ajhtl.19770720-15

Bernhard, I., \& Olsson, A.K. (2020). Network collaboration for local and regional development - The case of Swedish WOMen entrepreneurs. International Journal of Entrepreneurship and Small Business, 41(4), 539-561. https://doi.org/10.1504/IJESB.2020.111578

Booyens, I., \& Rogerson, C.M. (2015). Creative Tourism in Cape Town: An Innovation Perspective. Urban Forum, $26(4), 405-424$. https://doi.org/10.1007/s12132-015-9251-y

Braun, E., Eshuis, J., Klijn, E.H., \& Zenker, S. (2018). Improving place reputation: Do an open place brand process and an identity-image match pay off? Cities, 80, 22-28. https://doi.org/10.1016/j.cities.2017.06.010

Cassinger, C., \& Eksell, J. (2017). The magic of place branding: regional brand identity in transition. Journal of Place Management and Development, 10(3), 202-212. https://doi.org/10.1108/JPMD-03-2017-0028

Chen, N.C., Dwyer, L., \& Firth, T. (2018). Residents' place attachment and word-of-mouth behaviours: A tale of two cities. Journal of Hospitality and Tourism Management, 36, 1-11. https://doi.org/10.1016/j.jhtm.2018.05.001

Chin, C.H., Chin, C.L., \& Wong, W.P.M. (2018). The Implementation of Green Marketing Tools in Rural Tourism: The Readiness of Tourists? Journal of Hospitality Marketing and Management, 27(3), 261-280. https://doi.org/10.1080/19368623.2017.1359723

Ching-Cheng, S., \& Der-Jen, L. (2015). Correlation between the homestay experience and brand equity: Using the Yuehetang Rural Residence as a case study. Journal of Hospitality and Tourism Technology, 6(1), 59-72. https://doi.org/10.1108/JHTT-01-2015-0008

Clarke, I., \& Kredens, K. (2018). 'I consider myself to be a service provider': Discursive identity construction of the foren sic linguistic expert. International Journal of Speech, Language and the Law, 25(1), 79-107. https://doi.org/10.1558/ijsll.34457

Cleave, E., \& Arku, G. (2020). Place branding and growth machines: Implications for spatial planning and urban development. Journal of Urban Affairs. https://doi.org/10.1080/07352166.2020.1768104

Coffin, J. (2019). Deleuzoguattarian place marketing: becoming, between, beneath and beyond. Journal of Place Management and Development, 13(3), 229-240. https://doi.org/10.1108/JPMD-01-2019-0003 
Eugenio-Vela, J.D.S., Ginesta, X., \& Kavaratzis, M. (2020). The critical role of stakeholder engagement in a place branding strategy: a case study of the Empordà brand. European Planning Studies, 28(7), 1393-1412. https://doi.org/10.1080/09654313.2019.1701294

Fernandes, T., \& Fernandes, F. (2018). Sharing Dissatisfaction Online: Analyzing the Nature and Predictors of Hotel Guests Negative Reviews. Journal of Hospitality Marketing and Management, 27(2), 127-150. https://doi.org/10.1080/19368623.2017.1337540

Fullerton, J., \& Kendrick, A. (2017). Country reputation as a moderator of tourism advertising effectiveness. Journal of Marketing Communications, 23(3), 260-272. https://doi.org/10.1080/13527266.2014.973436

Gartner, W.C. (2014). Brand equity in a tourism destination. Place Branding and Public Diplomacy, 10(2), 108-116. https://doi.org/10.1057/pb.2014.6

Gómez, M., Fernández, A.C., Molina, A., \& Aranda, E. (2018). City branding in European capitals: An analysis from the visitor perspective. Journal of Destination Marketing and Management, 7, 190-201. https://doi.org/10.1016/j.jdmm.2016.11.001

Górska-Warsewicz, H. (2020). Factors determining city brand equity-A systematic literature review. Sustainability (Switzerland), 12(19). https://doi.org/10.3390/SU12197858

Grohs, R., Wieser, V.E., \& Pristach, M. (2020). Value cocreation at sport events. European Sport Management Quarterly, $20(1), 69-87$. https://doi.org/10.1080/16184742.2019.1702708

Han, H., Kiatkawsin, K., Jung, H., \& Kim, W. (2018). The role of wellness spa tourism performance in building destination loyalty: the case of Thailand. Journal of Travel and Tourism Marketing, 35(5), 595-610. https://doi.org/10.1080/10548408.2017.1376031

Hernández-Mogollón, J.M., Duarte, P.A., \& Folgado-Fernández, J.A. (2018). The contribution of cultural events to the formation of the cognitive and affective images of a tourist destination. Journal of Destination Marketing and Management, 8, 170-178. https://doi.org/10.1016/j.jdmm.2017.03.004

Hsieh, Y.C., Lin, K.Y., Lu, C., \& Rong, K. (2017). Governing a sustainable business ecosystem in Taiwan's circular economy: The story of spring pool glass. Sustainability (Switzerland), 9(6). https://doi.org/10.3390/su9061068

Ilieş, G., \& Ilieş, M. (2015). Identity based geo- and tourism branding strategies derived from rural maramure? Land (Romania). Geojournal of Tourism and Geosites, 16(2), 179-186.

Iordanova, E. (2015). Unravelling the complexity of destination image formation: A conceptual framework. European Journal of Tourism Research, 11, 35-56.

Jabreel, M., Huertas, A., \& Moreno, A. (2018). Semantic analysis and the evolution towards participative branding: Do locals communicate the same destination brand values as DMOs? PLOS ONE, 13(11). https://doi.org/10.1371/journal.pone.0206572

Jászberényi, M., \& Miskolczi, M. (2020). Danube cruise tourism as a niche product-An overview of the current supply and potential. Sustainability (Switzerland), 12(11). https://doi.org/10.3390/su12114598

Joo, Y.M., \& Seo, B. (2018). Transformative city branding for policy change: The case of Seoul's participatory branding. Environment and Planning C: Politics and Space, 36(2), 239-257. https://doi.org/10.1177/2399654417707526

Kankhuni, Z. (2020). Tourism destination branding in Malawi: A supply-side perspective. African Journal of Hospitality, Tourism and Leisure, 9(1), 1-21.

Kavaratzis, M. (2020). Is 'City Branding' Worth Re-Visiting? Tijdschrift Voor Economische En Sociale Geografie, 111(1), 24-27. https://doi.org/10.1111/tesg. 12403

Kavaratzis, M., \& Kalandides, A. (2015). Rethinking the place brand: the interactive formation of place brands and the role of participatory place branding. Environment and Planning A, 47(6), 1368-1382. https://doi.org/10.1177/0308518X15594918

Kavoura, A., \& Bitsani, E. (2014). Investing in culture and intercultural relations for advertising and sustainable development of the contemporary european city within the framework of international city branding and marketing: The case study of the intercultural festival of trieste, Ital. In Advertising: Types of Methods, Perceptions and Impact on Consumer Behavior, 35-65.

Kladou, S., Kavaratzis, M., Rigopoulou, I., \& Salonika, E. (2017). The role of brand elements in destination branding. Journal of Destination Marketing and Management, 6(4), 426-435. https://doi.org/10.1016/j.jdmm.2016.06.011

Koodsela, W., Dong, H., \& Sukpatch, K. (2019). A Holistic Conceptual Framework into Practice-Based on Urban Tourism Toward Sustainable Development in Thailand. Sustainability (Switzerland), 11(24). https://doi.org/10.3390/su11247152

Lee, R., \& Lee, Y.I. (2019). The role of nation brand in attracting foreign direct investments: a case study of Korea. International Marketing Review. https://doi.org/10.1108/IMR-01-2019-0024

Leković, K., Tomić, S., Marić, D., \& Ćurčić, N.V. (2020). Cognitive component of the image of a rural tourism destination as a sustainable development potential. Sustainability (Switzerland), 12(22), 1-12. https://doi.org/10.3390/su12229413

Li, J., Kim, W.G., \& Wong, I.A. (2017). Does destination perception differ based on traveler type? A case of the world gambling capital: Macau. Tourism Planning and Development, 14(1), 15-30. https://doi.org/10.1080/21568316.2016.1152289

Li, Y., Xu, X., Song, B., \& He, H. (2020). Impact of short food videos on the tourist destination image-Take Chengdu as an example. Sustainability (Switzerland), 12(17). https://doi.org/10.3390/SU12176739

Lindstedt, J. (2015). A deliberately emergent strategy - A key to successful city branding. Journal of Place Management and Development, 8(2), 90-102. https://doi.org/10.1108/JPMD-12-2014-0029

Makarov, P.Y., \& Illarionov, A.E. (2020). The role of regional administrations in improving place branding effectiveness: An exploratory study. Journal of Place Management and Development, 13(4), 409-427. https://doi.org/10.1108/JPMD-06-2019-0045

Mangano, S., \& Ugolini, G.M. (2020). New opportunities for cruise tourism: The case of Italian historic towns. Sustainability (Switzerland), 12(11). https://doi.org/10.3390/su12114616

Mariutti, F.G., \& de Moura Engracia Giraldi, J. (2019). How does a Brand Reputation-Driven Construct Impact on Country Brand Equity? A Cross-National Study of Brazil and China. Journal of International Consumer Marketing, 31(5), 408-428. https://doi.org/10.1080/08961530.2019.1590280

Martens, H.M., \& Reiser, D. (2019). Analysing the image of Abu Dhabi and Dubai as tourism destinations - The perception of first-time visitors from Germany. Tourism and Hospitality Research, 19(1), 54-64. https://doi.org/10.1177/1467358417690436

Martin, E., \& Capelli, S. (2018). Place brand communities: from terminal to instrumental values. Journal of Product and Brand Management, 27(7), 793-806. https://doi.org/10.1108/JPBM-10-2017-1654

Mason, M.C., \& Moretti, A. (2015). Antecedents and moderators of golf tourists' behavioral intentions: An empirical study in a Mediterranean destination. EuroMed Journal of Business, 10(3), 338-359. https://doi.org/10.1108/EMJB-10-2014-0033

Mastika, I.K. (2020). Destination branding model of an ecological tourism village in Bali, Indonesia. Geojournal of Tourism and Geosites, 31(3), 1068-1074. https://doi.org/10.30892/gtg.31319-542 
Melewar, T.C., \& Skinner, H. (2020). Territorial brand management: Beer, authenticity, and sense of place. Journal of Business Research, 116, 680-689. https://doi.org/10.1016/j.jbusres.2018.03.038

Mlambo, S.S., \& Ezeuduji, I.O. (2020). South Africa's Kwazulu-natal tourism destination brand essence and competitiveness: Tourists' perspectives. Geojournal of Tourism and Geosites, 32(4), 1195-1201. https://doi.org/10.30892/GTG.32401-557

Mohd Shariff, N., \& Zainol Abidin, A. (2020). Stakeholders, social responsibility and remuneration practices in the Malaysian tourism small and medium-sized enterprises. Geojournal of Tourism and Geosites, 29(2), 684-693. https://doi.org/10.30892/gtg.29224-499

Munawir (2019). Visitor perceptions and effectiveness of place branding strategies in thematic parks in Bandung City using text mining based on google maps user reviews. Sustainability (Switzerland), 11(7). https://doi.org/10.3390/SU11072123

Papadimitriou, D., Kaplanidou, K., \& Apostolopoulou, A. (2018). Destination Image Components and Word-of-Mouth Intentions in Urban Tourism: A Multigroup Approach. Journal of Hospitality and Tourism Research, 42(4), 503-527. https://doi.org/10.1177/1096348015584443

Park, D., Lee, G., Kim, W.G., \& Kim, T.T. (2019). Social network analysis as a valuable tool for understanding tourists' multi-attraction travel behavioral intention to revisit and recommend. Sustainability (Switzerland), 11(9). https://doi.org/10.3390/su11092497

Petrevska, B., \& Cingoski, V. (2017). Branding the green tourism in Macedonia. Sociologija i Prostor, 55(1), 101-116. https://doi.org/10.5673/sip.55.1.5

Reijonen, H., Rogerson, C.M., Saffu, K., Obeng Apori, S., Elijah-Mensah, A., Ahumatah, J., \& Rudd, D. (2017). From space technology transfer and space systems utilisation to start-ups creation: The European Space Incubators Network. Tourism Management, 10(1), 1-19. https://doi.org/10.1007/978-94-007-2288-0

Reitsamer, B.F., \& Brunner-Sperdin, A. (2015). Tourist destination perception and well-being: What makes a destination attractive? Journal of Vacation Marketing, 23(1), 55-72. https://doi.org/10.1177/1356766715615914

Rodrigues, C., Skinner, H., Dennis, C., \& Melewar, T.C. (2019). Towards a theoretical framework on sensorial place brand identity. Journal of Place Management and Development, 13(3), 273-295. https://doi.org/10.1108/JPMD-11-2018-0087

Salim Saji, B., Vij, M., \& Kabiraj, S. (2015). Selection of Tourism Destination as a Representation of Human Values. Business Perspectives and Research, 3(2), 95-108. https://doi.org/10.1177/2278533715578554

Sánchez-Rivero, M., Rodríguez-Rangel, M.C., \& Fernández-Torres, Y. (2020). The identification of factors determining the probability of practicing Inland water tourism through logistic regression models: The case of Extremadura, Spain. Water (Switzerland), 12(6). https://doi.org/10.3390/W12061664

Sannassee, R. V, \& Seetanah, B. (2015). The Influence of Trust on Repeat Tourism: The Mauritian Case Study. Journal of Hospitality Marketing and Management, 24(7), 770-789. https://doi.org/10.1080/19368623.2014.934983

Stylos, N., \& Bellou, V. (2019). Investigating Tourists' Revisit Proxies: The Key Role of Destination Loyalty and Its Dimensions. Journal of Travel Research, 58(7), 1123-1145. https://doi.org/10.1177/0047287518802100

Sukmayana, D., \& Mukti, B.A. (2017). The analysis of services value through public relation marketing, integrated marketing communication and self-image in order to increase public satisfaction: (An empirical study of services by the members of the Regional House of representatives in West Java province). International Journal of Applied Business and Economic Research, 15(6), $151-171$.

Sumartias, S., \& Nuraryo, I. (2017). Student satisfaction, University brand image and its impact on word-of-mouth communication. International Journal of Applied Business and Economic Research, 15(19), 475-483.

Thi, L., Pham, M., Do, H.N., \& Phung, T.M. (2016). The effect of brand equity and perceived value on customer revisit intention : a study in quick-service restaurants in vietnam. Acta Oeconomica Pragensia, Prague University of Economics and Business. 24(05), 14-30. https://doi.org/10.18267/j.aop.555

Thi, V., Thuy, N., Doan, H., \& Thao, P. (2016). Impact of students' experiences on brand image perception : the case of Vietnamese higher education. International Review on Public and Nonprofit Marketing. https://doi.org/10.1007/s12208-016-0171-x

Toros, E., \& Gazibey, Y. (2018). Priorities of the citizens in city brand development: comparison of two cities (Nicosia and Kyrenia) by using analytic hierarchy process (AHP) approach. Quality and Quantity, 52, 413-437. https://doi.org/10.1007/s11135-017-0622-4

Tosun, C., Bora, B., \& Fyall, A. (2015). Journal of Destination Marketing \& Management Destination service quality, affective image and revisit intention : The moderating role of past experience, 4, 222-234. https://doi.org/10.1016/j.jdmm.2015.08.002

Tsaur, S.H., Yen, C.H., Tu, J.H., Wang, C.H., \& Liang, Y.W. (2017). Evaluation of the 2010 Taipei International Flora Exposition from the perceptions of host-city residents: a new framework for mega-event legacies measurement. Leisure Studies, 36(1), 65-88. https://doi.org/10.1080/02614367.2015.1037786

Utomo, S.H., Wulandari, D., Narmaditya, B.S., Ishak, S., Prayitno, P.H., Sahid, S., \& Qodri, L.A. (2020). Rural-based tourism and local economic development: Evidence from Indonesia. Geojournal of Tourism and Geosites, 31(3), 1161-1165. https://doi.org/10.30892/GTG.31330-553

Venus, A., Octavianti, M., \& Setiaman, A. (2019). The use of instagram to make a successful destination branding in West Java Indonesia. International Journal of Scientific and Technology Research, 8(9), 903-907.

Wassler, P., Schuckert, M., Hung, K., \& Petrick, J.F. (2018). You're welcome? Hong Kong's attitude towards the Individual Visit Scheme. International Journal of Tourism Research, 20(5), 637-649. https://doi.org/10.1002/jtr.2212

Windupranata, W., Hanifa, N.R., Nusantara, C.A.D.S., Aristawati, G., \& Arifianto, M.R. (2020). Analysis of tsunami hazard in the Southern Coast of West Java Province - Indonesia. In 2nd Maritime Science and Advanced Technology: Marine Science and Technology in Framework of The Sustainable Development Goals, MSAT 2019, 618, Research Group of Coastal, Ocean and Maritime Engineering, Faculty of Earth Sciences and Technology, Institut Teknologi Bandung, Indonesia: IOP Publishing Ltd. https://doi.org/10.1088/1755-1315/618/1/012026

Zeng, S., Gao, L., Shen, R., Ma, Y., \& Li, H. (2020). Fiscal decentralization, pollution and China's tourism revenue. Sustainability (Switzerland), 12(5). https://doi.org/10.3390/su12051925

Zenker, S., \& Braun, E. (2017). Questioning a "one size fits all" city brand: Developing a branded house strategy for place brand management. Journal of Place Management and Development, 10(3), 270-287. https://doi.org/10.1108/JPMD-04-2016-0018

Zenker, S., Braun, E., \& Petersen, S. (2017). Branding the destination versus the place: The effects of brand complexity and identification for residents and visitors. Tourism Management, 58, 15-27. https://doi.org/10.1016/j.tourman.2016.10.008

\footnotetext{
Article history: Received: 24.11.2020 Revised: 18.02.2021 Accepted: 19.04.2021 Available online: 11.05 .2021
} 